\title{
EFEKTIFITAS KOMBINASI PERAWATAN PAYUDARA DAN PIJAT OKSITOSIN TERHADAP PRODUKSI ASI PADA IBU POST PARTUM DI BPM SETIA
}

\section{Effectiveness of Combination of Breast Care and Oxytocin Massage on Breast Feeding Production in Mother Post Partum in BPM Setia}

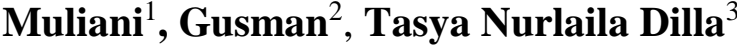 \\ 1,2Poltekkes Kemenkes Palu \\ ${ }^{3}$ DIV Kebidanan Poltekkes Kemenkes Palu \\ (murid_lewa@yahoo.co.id/081225695269)
}

\begin{abstract}
ABSTRAK
Prevalensi pemberian ASI eksklusif terhitung rendah. Pada tahun 2016, cakupan ASI eksklusif Puskesmas Kamonji yaitu 57,89\% di Kota Palu. Metode yang digunakan untuk melancarkan produksi ASI yaitu kombinasi perawatan payudara dan pijat oksitosin. Hal ini dikarenakan metode tersebut berfungsi membantu merangsang hormon prolaktin dan oksitosin serta mencegah tersumbatnya saluran susu. Tujuan penelitian ini adalah diketahuinya efektifitas kombinasi perawatan payudara dan pijat oksitosin terhadap produksi ASI pada ibu postpartum di BPM Setia wilayah kerja Puskesmas Kamonji. Jenis penelitian quasi experimental, dengan posttest-only control design. Digunakan rumus replikasi untuk pemilihan subjek dengan total subjek sebanyak 32 orang, menggunakan teknik consecutive sampling. Pemberian intervensi dilakukan sejak hari pertama hingga hari ketiga postpartum kemudian dilakukan observasi. Uji normalitas data menggunakan uji Shapiro-Wilk, analisis data menggunakan uji independent t-test. Hasil penelitian diperoleh nilai significancy sebesar 0,004 dengan jumlah rerata kelompok kombinasi adalah 4,49 cc dan kelompok kontrol adalah 3,23 cc. Perbedaan rerata antara kedua kelompok adalah 1,26 cc. Kesimpulan penelitian ini adalah kombinasi perawatan payudara dan pijat oksitosin efektif terhadap produksi ASI pada ibu postpartum. Berdasarkan hasil penelitian ini disarankan untuk mengembangkan pelayanan dengan memberikan intervensi kombinasi pada ibu postpartum untuk membantu meningkatkan ASI.
\end{abstract}

Kata kunci : Air susu ibu, perawatan payudara, pijat oksitosin

ABSTRACT

The prevalence of exclusive breastfeeding is low. In 2016, the exclusive ASI coverage of Kamonji Public Health Center was 57.89\% in Palu City. The method used to launch ASI production is a combination of breast care and oxytocin massage. This is because the method works to help stimulate the hormone prolactin and oxytocin and prevent blockage of the milk ducts. The purpose of this study was to find out the effectiveness of the combination of breast care and oxytocin massage on breast milk production in postpartum mothers at BPM Setia in the Kamonji Community Health Center work area. This type of research is quasi experimental, with posttest-only control design. Replication formula is used for the selection of subjects with a total of 32 subjects, using consecutive sampling technique. The intervention was given from the first day to the third day postpartum and then observation was made. Data normality test using the Shapiro-Wilk test, data analysis using independent $t$-test. The results obtained by the significance value of 0.004 with the mean number of combination groups was $4.49 \mathrm{cc}$ and the control group was $3.23 \mathrm{cc}$. The mean difference between the two groups was $1.26 \mathrm{cc}$. The conclusion of this study is a combination of breast care and oxytocin massage effective against breast milk production in postpartum mothers. Based on the results of this study it is suggested to develop services by providing combined intervention for postpartum mothers to help increase breastfeeding

Keywords : Breast feeding, breast care, oxytocin massage 


\section{PENDAHULUAN}

Prevalensi pemberian Air Susu Ibu (ASI) eksklusif di dunia masih terhitung rendah. Berdasarkan data dari United Nations Children's Fund (UNICEF) pada tahun 2012 hanya 39\% bayi di bawah usia 6 bulan yang mendapatkan ASI secara eksklusif di seluruh dunia $^{(1)}$. Provinsi Sulawesi Tengah berada di peringkat ke-6 dari yang terendah dengan persentase sebesar $21,0 \%^{(2)}$. Cakupan ASI eksklusif Kota Palu yang merupakan ibukota dari Provinsi Sulawesi Tengah pada tahun 2016 yaitu 64,4\% dan menduduki urutan ke-4 dari yang tertinggi ${ }^{(3)}$. Pada tahun 2016, Puskesmas Kamonji berada pada urutan ke-4 dari yang terendah namun dengan persentase sebesar $57,89 \%^{(4)}$.

World Health Organization (WHO) menyimpulkan bahwa sekitar $35 \%$ ibu menghentikan pemberian ASI secara eksklusif pada beberapa minggu postpartum karena beranggapan bahwa produksi ASI-nya kurang dan bayi merasa tidak puas ${ }^{(5)}$.

Terdapat beberapa upaya dalam meningkatkan produksi ASI, seperti halnya melakukan pijat oksitosin yang berfungsi untuk merilekskan otot yang kaku dan menghilangkan stres sehingga dapat membantu merangsang hormon prolaktin dan oksitosin ${ }^{(6)}$. Cara ini akan lebih efektif bila dikombinasikan dengan perawatan payudara yang bertujuan untuk merawat dan memelihara payudara, melancarkan sirkulasi darah dan mencegah tersumbatnya saluran susu ${ }^{(7)}$ Penelitian sebelumnya menunjukkan bahwa ada peningkatan kelancaran produksi ASI pada ibu yang dipijat oksitosin dan 8,45 kali lebih berpeluang bila dibandingkan dengan ibu yang tidak dipijat oksitosin ${ }^{(8)}$. Penelitian lain menunjukkan bahwa perawatan payudara berpengaruh dengan pengeluaran $\mathrm{ASI}^{(9)}$.

Dalam penelitian ini, peneliti melakukan intervensi sesuai dengan terapi untuk produksi dan pengeluaran ASI yang meliputi tindakan perawatan dan pemijatan. Mengombinasikan perawatan payudara dan pijat oksitosin yang diharapkan akan berpengaruh terhadap produksi ASI.

\section{METODE PENELITIAN}

Jenis penelitian quasi experimental dengan pendekatan posttest-only control design. Kelompok eksperimen mendapatkan perlakuan kombinasi perawatan payudara dan pijat oksitosin dan kelompok kontrol hanya diberikan intervensi perawatan payudara, selanjutnya kedua kelompok diikuti dengan observasi, kemudian membandingkan hasil observasi dari kelompok eksperimen dengan kelompok kontrol. kontrol.

Penelitian ini dilaksanakan di BPM Setia pada tanggal 25 April-30 Mei 2018. Populasi penelitian adalah ibu-ibu bersalin Teknik pemilihan sampel secara consecutive sampling dengan jumlah sampel 16 responden untuk masing-masing kelompok. Sampel sesuai kriteria adalah ibu bersalin dengan kehamilan aterm (37-42 minggu) tanpa komplikasi dan belum ada pengeluaran ASI sampai 2 jam post partum. Pengumpulan data dilakukan secara langsung pemberian 
intervensi berupa perawatan payudara dan pijat oksitosin setelah 2 jam postpartum dan dilakukan observasi setiap hari selama 3 hari sesuai masa keluarnya kolostrum. Analisis data dengan uji Shapiro Wilk selanjutnya analisis ttest tidak berpasangan. Data disajikan dalam bentuk narasi dan tabel. Bahan dan alat pendukung yang digunakan dalam intervensi berupa wadah air hangat dan dingin, washlap 2 buah, untuk pengompresan dan pembersihan, baby oil untuk pijat dengan aroma yang menenangkan.

\section{HASIL}

Pada tabel 1 kelompok kombinasi perawatan payudara dan pijat oksitosin $75 \%$ atau 12 dari 16 responden berada pada rentangan umur 20-35 tahun, serta 13 responden pada kelompok kontrol (81,3\%).
Karakteristik multipara masing-masing 9 responden $(56,3 \%)$ pada kedua kelompok. Tabel 2 menunjukkan jumlah total rerata produksi ASI pada kelompok intervensi kombinasi selama 3 hari yaitu $71,87 \mathrm{cc}$, sedang pada kelompok kontrol sebanyak 51,77 cc.

Tabel 1. Distribusi Karakteristik Responden Kombinasi Perawatan dan Kelompok Kontrol di BPM Setia Wilayah Kerja Puskesmas Kamonji, Tahun 2018

\begin{tabular}{lcccc}
\hline Karakteristik & $\begin{array}{c}\text { Kelompok } \\
\text { Kombinasi* } \\
\text { n=16 }\end{array}$ & $\begin{array}{c}\text { Kontrol** } \\
\mathbf{n = 1 6}\end{array}$ \\
\hline Umur (thn) & 1 & $6,3 \%$ & 2 & $12,5 \%$ \\
$<20$ & 12 & $75 \%$ & 13 & $81,3 \%$ \\
$20-35$ & 3 & $18,8 \%$ & 1 & $6,3 \%$ \\
$\quad>35$ & & & & \\
Paritas & 5 & $31,3 \%$ & 5 & $31,3 \%$ \\
$\quad$ Primipara & 9 & $56,3 \%$ & 9 & $56,3 \%$ \\
$\quad$ Multipara & 2 & $12,5 \%$ & 2 & $12,5 \%$ \\
$\quad$ Grandemultipara & & & \\
\hline $\begin{array}{l}\text { Sumber: Data Primer, } 2018 \\
\text { *Perawatan Payudara dan Pijat Oksitosin }\end{array}$ \\
**Perawatan payudara
\end{tabular}

Tabel 2. Distribusi Jumlah Produksi ASI Kelompok Kombinasi Perawatan Payudara dan Pijat Oksitosin dengan Kelompok Kontrol Perawatan Payudara di BPM Setia Wilayah Kerja Puskesmas Kamonji Tahun 2018

\begin{tabular}{|c|c|c|c|c|c|}
\hline \multirow{2}{*}{$\begin{array}{l}\text { No. } \\
\text { Resp }\end{array}$} & \multicolumn{2}{|c|}{$\begin{array}{l}\text { Kombinasi* } \\
\text { (cc) }\end{array}$} & \multirow{2}{*}{$\begin{array}{l}\text { No. } \\
\text { Resp }\end{array}$} & \multicolumn{2}{|c|}{$\begin{array}{c}\begin{array}{c}\text { Kontrol } \\
\text { (cc) }\end{array} \\
\end{array}$} \\
\hline & $\begin{array}{c}\text { Jumlah ASI dari hari } \\
\text { pertama-ketiga }\end{array}$ & Rerata ASI & & $\begin{array}{l}\text { Jumlah ASI hari } \\
\text { pertama-ketiga }\end{array}$ & Rerata ASI \\
\hline $1 \mathrm{a}$ & 13.2 & 4.4 & $1 b$ & 9 & 3 \\
\hline $2 \mathrm{a}$ & 15.4 & 5.13 & $2 b$ & 14.6 & 4.87 \\
\hline $3 a$ & 15.2 & 5.07 & $3 b$ & 8.4 & 2.8 \\
\hline $4 a$ & 14.6 & 4.87 & $4 \mathrm{~b}$ & 10.2 & 3.4 \\
\hline $5 a$ & 10.4 & 3.47 & $5 b$ & 9.4 & 3.13 \\
\hline $6 a$ & 17 & 5.67 & $6 b$ & 6.6 & 2.2 \\
\hline $7 \mathrm{a}$ & 8.8 & 2.93 & $7 b$ & 13.2 & 4.4 \\
\hline $8 \mathrm{a}$ & 19.6 & 6.53 & $8 b$ & 5.2 & 1.73 \\
\hline $9 \mathrm{a}$ & 15 & 5 & $9 b$ & 17.2 & 5.73 \\
\hline $10 \mathrm{a}$ & 14.6 & 4.87 & $10 \mathrm{~b}$ & 3.2 & 1.07 \\
\hline $11 \mathrm{a}$ & 15 & 5 & $11 b$ & 14 & 4.67 \\
\hline $12 \mathrm{a}$ & 11.6 & 3.87 & $12 b$ & 6 & 2 \\
\hline $13 a$ & 8.4 & 2.8 & $13 b$ & 9.6 & 3.2 \\
\hline $14 \mathrm{a}$ & 14.4 & 4.8 & $14 \mathrm{~b}$ & 8.4 & 2.8 \\
\hline $15 \mathrm{a}$ & 8.2 & 2.73 & $15 b$ & 10.8 & 3.6 \\
\hline $16 \mathrm{a}$ & 14.2 & 4.73 & $16 \mathrm{~b}$ & 9.5 & 3.17 \\
\hline Jumlah & 215.6 & 71.87 & Jumlah & 155.3 & 51.77 \\
\hline
\end{tabular}

Sumber: Data Primer, 2018

*Perawatan Payudara dan Pijat Oksitosin

**Perawatan payudara 
Tabel 2 menunjukkan jumlah total rerata produksi ASI pada kelompok intervensi kombinasi selama 3 hari yaitu 71,87 cc, sedang pada kelompok kontrol sebanyak 51,77 cc. Tabel 3 menunjukkan rerata produksi ASI pada kelompok kombinasi adalah 4,49 cc, dan pada kelompok kontrol adalah 3,23 cc. Perbedaan rerata jumlah produksi ASI pada kedua kelompok adalah 1,26 cc, dengan nilai $\rho$-value $=0,004(<0.05)$.

Tabel 3. Analisis Uji Independent t-test Pada Efektifitas Kombinasi Perawatan Payudara dan Pijat Oksitosin Terhadap Produksi ASI Pada Ibu Postpartum di BPM Setia Wilayah Kerja Puskesmas Kamonji

\begin{tabular}{ccccc} 
Produksi ASI & n & Mean & $\begin{array}{c}\text { Beda } \\
\text { rerata }\end{array}$ & $\begin{array}{c}\rho- \\
\text { value }\end{array}$ \\
\hline $\begin{array}{c}\text { Kombinasi* } \\
\text { Kontrol** }\end{array}$ & 16 & 4,49 & 1,26 & 0,004 \\
\hline
\end{tabular}

Sumber: Data Primer, 2018

*Perawatan Payudara dan Pijat Oksitosin

**Perawatan payudara

\section{PEMBAHASAN}

Karakteristik pada kedua kelompok relatif sama, baik umur maupun paritas responden, data tersebut terdistribusi normal yang dibuktikan hasil uji normalitas data dengan Shapiro-Wilk diperoleh nilai $\rho$-value sebesar 0,196 (>0,05), selanjutnya dilakukan uji statistik secara independent $t$-test.

Hasil analisis deskriptif, menunjukkan beda rata-rata jumlah produksi ASI selama 3 hari dilakukan intervensi pada kelompok kombinasi sebanyak 71,87 cc dan kelompok kontrol 51,77 cc, sehinggga terdapat selisih rerata 20,1 cc lebih besar dibanding pada kelompok kontrol, dan sebagian besar responden memiliki produksi ASI yang $\geq 2 \mathrm{cc}$ pada hari pertama.

Berdasarkan hasil uji independent $t$ test pada tingkat kepercayaan 95\% diperoleh nilai $\rho$-value sebesar $0,004(<0,05)$, sehingga dapat diketahui bahwa kombinasi perawatan payudara dan pijat oksitosin lebih efektif terhadap jumlah produksi ASI 1,26 cc lebih banyak dibanding pada ibu yang hanya mendapatkan perawatan payudara.

Sejalan dengan penelitian sebelumnya yang mengukur produksi ASI ibu post sectio caesarea hari ke-5 yang diberikan intervensi kombinasi pijat oksitosin dan breast care dengan indikator frekuensi BAK bayi diketahui bahwa $91,43 \%$ atau 32 bayi memiliki frekuensi $\mathrm{BAK} \geq 6$ kali dengan $\rho$-value 0,001 sehingga dapat dinyatakan bahwa intervensi kombinasi breast care dan pijat oksitosin efektif untuk meningkatkan produksi ASI ${ }^{(10)}$. Penelitiaan ini tidak relevan dengan penelitian sebelumnya yang menunjukkan hasil bahwa tidak terdapat perbedaan produksi ASI pada ibu postpartum berdasarkan jenis persalinan (11).

Pada pijat oksitosin, dapat dilakukan pada ibu dalam posisi duduk dengan santai sambil menyandarkan kepala ke depan pada meja/tempat tidur dengan melipat lengan dan meletakkan kepala di atas lengan sehingga ibu merasa lebih nyaman, hal ini diharapkan agar perasaan negatif dapat diminimalisir. Selain untuk memberikan kenyamanan pada ibu, manfaat pijat oksitosin adalah untuk 
merangsang reflex let down, mengurangi sumbatan ASI, merangsang pelepasan hormon oksitosin dan mempertahankan produksi ASI.

Demikian halnya faktor psikologik yang terganggu dapat meningkatkan hormon adrenalin sehingga menghambat pelepasan hormon oksitosin yang akan berpengaruh terhadap produksi ASI (12). Terganggunya kondisi psikis yang disebabkan oleh ketidaknyamanan ataupun stres yang dialami oleh ibu menyusui secara otomatis dapat mempengaruhi produksi hormon oksitosin yang berperan dalam memproduksi ASI yang berkualitas, hal ini dikarenakan bahwa ASI yang diproduksi ibu tidak lepas dari keselarasan pikiran dan jiwa ${ }^{(13)}$.

Penelitian lain menunjukkan relevansi bahwa rerata sekresi ASI antara pretest dan post-test dalam kelompok eksperimen adalah 203,82 cc dan kelompok kontrol adalah 54,9 cc dengan $\rho$-value $0,000(<0,05)$ sehingga dapat dinyatakan terdapat peningkatan yang cukup signifikan dari kombinasi perawatan payudara dan pijat oksitosin dalam meningkatkan sekresi ASI pada ibu postpartum di wilayah kerja Puskesmas Batealit Jepara ${ }^{(14)}$.

Pijat oksitosin juga merupakan salah satu solusi untuk mengatasi ketidaklancaran produksi ASI. Pemijatan ini dilakukan pada sepanjang tulang belakang (vertebrae) sampai tulang costae ke-V dan VI guna merangsang hormon prolaktin dan oksitosin setelah melahirkan. Salah satu hormon yang berperan dalam produksi ASI adalah hormon oksitosin, sehingga saat terjadi stimulasi hormon oksitosin maka sel-sel alveoli di kelenjar payudara berkontraksi. Kontraksi inilah yang menyebabkan ASI keluar lalu mengalir dalam saluran payudara sehingga keluarlah tetesan air susu dari puting payudara ${ }^{(15)}$.

Pijat stimulasi oksitosin untuk ibu menyusui berfungsi untuk merangsang hormon oksitosin sebagai hormon cinta agar dapat memperlancar ASI dan meningkatkan kenyamanan ibu, sehingga akan memberikan kenyamanan pada bayi yang disusui. Oksitosin diproduksi oleh kelenjar pituitari posterior (neurohipofisis). Saat bayi mengisap areola akan mengirimkan stimulasi ke neurohipofisis untuk memproduksi dan melepaskan oksitosin secara intermiten. Oksitosin akan masuk ke aliran darah ibu dan merangsang sel otot di sekeliling alveoli berkontraksi membuat ASI yang telah terkumpul di dalamnya mengalir ke saluran-saluran duktus.

Saat dilakukan pemijatan pada tulang belakang dapat menimbulkan reflek neurogenik yang mempercepat kerja saraf parasimpatis untuk menyampaikan perintah ke otak bagian belakang. Akibat sinyal stimulatorik, lalu ada proses potensial aksi oksitosin dilepaskan ke dalam darah sistemik dari hipofisis posterior. Lalu dalam aliran darah, oksitosin disampaikan ke sel mioepitel alveoli dan uterus sehingga oksitosin akan merangsang sel tersebut yang mengakibatkan kantung alveolus tertekan dan duktus memendek serta melebar ${ }^{(16)}$.

Selain pemberian pijat oksitosin, juga terdapat metode perawatan payudara yang 
sangat penting untuk memperlancar pengeluaran ASI dengan merangsang kelenjarkelenjar air susu melalui pemijatan. Hasil penelitian sebelumnya menunjukkan ada hubungan perawatan payudara terhadap kelancaran ekskresi ASI dengan nilai $\rho$-value sebesar 0,018 (<0.05) dan nilai Ods Ratio (OR) menunjukkan hasil 1,615 yang berarti dengan dilakukannya perawatan payudara dapat mempengaruhi kelancaran ekskresi ASI 1,6 kali lebih besar dibandingkan yang tidak diberikan perawatan payudara ${ }^{(17)}$.

Penelitian sebelumnya telah menunjukkan bahwa rerata volume ASI sebelum perawatan payudara yaitu 4,5 cc sedangkan rerata sesudah perawatan payudara yaitu $6,44 \mathrm{cc}$ dengan nilai $\rho$-value 0,021 yang berarti bahwa terdapat pengaruh positif antara sebelum dan sesudah pemberian intervensi. Adapun intervensi perawatan payudara yang dilakukan dengan cara merangsang atau memijat payudara, membersihkan puting susu serta mengompres payudara menggunakan air hangat dan air dingin secara bergantian yang dapat mempengaruhi hipofisis untuk mengeluarkan hormon progesteron dan estrogen sehingga menghasilkan hormon oksitosin ${ }^{(18)}$.

Perawatan payudara dengan memberikan rangsangan terlebih dahulu pada otot-otot halus alveoli payudara untuk merangsang hormon oksitosin yang menyebabkan sel-sel mioepitel di sekitar alveoli akan berkontraksi dan mendorong ASI masuk dalam pembuluh ampulla (16).
Perawatan payudara pada hari-hari pertama masa nifas dapat melancarkan aliran darah pada payudara, selanjutnya mengurangi tekanan intraduktal yang diakibatkan oleh ASI yang terkumpul pada duktus laktiferus sehingga rangsangan ini dilanjutkan ke hipotalamus melalui medulla spinalis dan mesensephalon. Hipotalamus akan menekan merangsang pengeluaran faktor yang memicu sekresi prolaktin yang akan merangsang hipofise anterior untuk memproduksi prolaktin. Selanjutnya, hormon prolaktin akan merangsang sel alveoli untuk membuat air susu ${ }^{(19)}$.

Sehingga berdasarkan penjelasan tersebut, dapat disimpulkan jika kedua metode tersebut dikombinasikan maka akan lebih efektif terhadap kelancaran produksi dan pengeluaran ASI. Hal ini dikarenakan kombinasi atau penggabungan dari kedua metode tersebut yaitu pemijatan pada payudara lewat pemberian rangsang terhadap otot-otot payudara dan pemijatan di daerah punggung ibu dengan tujuan untuk memberikan rangsangan pada kelenjar air susu agar dapat memproduksi susu dan memicu hormon oksitosin atau refleks let down serta memberikan kenyamanan dan menciptkan rasa rileks pada ibu melalui hormon endorphin yang disekresi karena rasa nyaman dan rileks yang dialami selama pemijatan serta dukungan yang diberikan. Pikiran, perasaan dan sensasi yang dialami seorang ibu akan sangat berpengaruh terhadap refleks oksitosin sebagai hormon cinta. Hal inilah yang menyebabkan 
terjadinya peningkatan dari pengeluaran dan produksi ASI.

Berdasarkan penelitian-penelitian terdahulu terdapat bukti yang menunjukkan bahwa terdapat metode pijatan lain yang juga dapat dikombinasikan dan berpeluang dalam meningkatkan dan melancarkan produksi ASI. Oleh karena itu, dianjurkan pula untuk memberikan kombinasi dari beberapa metode pijatan lain misalnya pijat tengkuk, pijat endorphin atau pijat marmet meningkatkan kelancaran produksi ASI pada ibu postpartum.

Produksi dan pengeluaran ASI pada hari pertama kelahiran sangat bermanfaat bagi ibu dan bayi, karena hal ini dapat meningkatkan keberhasilan pemberian ASI eksklusif pada bayi karena bayi tidak perlu mendapatkan makanan pengganti ASI dengan alasan tidak adanya ASI yang keluar saat harihari pertama kelahiran, sehingga ibu takut bayinya akan kelaparan. Padahal seperti yang telah dipaparkan sebelumnya bahwa jumlah produksi ASI pada hari-hari pertama masih berkisar 2-20 cc. Selain itu, hal ini juga sangat bermanfaat bagi ibu karena oksitosin dibutuhkan oleh ibu untuk proses involusio uteri dan mencegah terjadinya perdarahan pada ibu.

Pengeluaran ASI yang lebih cepat akan memberikan kesempatan ibu untuk menyusui bayinya secara eksklusif dan menurunkan risiko terjadinya kegagalan pemberian ASI eksklusif pada bayi, serta jumlah ASI yang dilihat secara nyata dapat menghilangkan persepsi ketidakcukupan ASI yang selama ini mengganggu psikis ibu menyusui. Pentingnya ASI bagi bayi maka sudah seharusnya bayi mendapatkan ASI sesegera mungkin setelah lahir hingga usia 6 bulan. Hal ini sejalan pernyataan IDAI bahwa pemberian ASI eksklusif selama 4-6 bulan berhubungan dengan rendahnya kejadian penyakit karena adanya antibodi yang dapat menetralisir ${ }^{(13)}$.

Hasil penelitian ini dapat diterapkan di seluruh fasilitas kesehatan khususnya BPM dan Puskesmas yaitu dengan memberikan kombinasi perawatan payudara dan pijat oksitosin pada ibu postpartum untuk membantu meningkatkan produksi ASI. Sangat dianjurkan untuk memberikan informasi tentang perawatan payudara dan pijat oksitosin pada ibu sejak masa kehamilan dan melakukan perawatan payudara sejak hamil yaitu pada trimester ketiga. Hal ini dilakukan untuk menyiapkan payudara dan memastikan kelancaran ASI pada masa menyusui sehingga ibu bisa melakukan perawatan payudara secara mandiri dengan dukungan dari suami dan keluarga.

\section{KESIMPULAN DAN SARAN}

Berdasarkan hasil penelitian ini dapat disimpulkan bahwa kombinasi perawatan payudara dan pijat oksitosin efektif terhadap produksi ASI lebih besar pada ibu postpartum dibanding dengan hanya dilakukan perawatan payudara. 


\section{DAFTAR PUSTAKA}

1. UNICEF. 2013. ASIadalah penyelamat hidup paling murah dan efektif di dunia. UNICEF arcives. (Online), cited 14 Oct 2017

2. Kemenkes RI. 2017. Profil Kesehatan Indonesia Tahun 2016. Jakarta: Kementerian Kesehatan Republik Indonesia

3. Dinas Kesehatan Provinsi Sulawei Tengah. 2017. Data ASI Eksklusif Provinsi Sulawesi Tengah tahun 2016. Palu: Dinas Kesehatan Provinsi Sulteng

4. Dinas Kesehatan Kota Palu. 2017. Data ASI Eksklusif Kota Palu tahun 2016. Palu: Dinas Kesehatan Kota Palu

5. Fikawati, S., Syafiq, A., dan Karima, K. 2015. Gizi Ibu dan Bayi. Rajawali Pers: Jakarta

6. Maryunani, A. 2015. Inisiasi Menyusu Dini, ASI Eksklusif dan Manajeman Laktasi.TIM: Jakarta

7. 2011. Asuhan pada Ibu dalam Masa Nifas (POSTPARTUM).TIM: Jakarta

8. Sumiaty dan Pont, A.V. 2013. Efektivitas Pijat Oksitosin Terhadap Produksi Air Susu Ibu Post Partum di RSU Anutapura Palu. Riset Pembinaan Tenaga Kesehatan. Tidak dipublikasikan. Palu: Jurusan Kebidanan Poltekkes Kemenkes Palu

9. Meilirianta, Istianah, dan Yuliani, A. 2014. Pengaruh Perawatan Payudara terhadap Pengeluaran Air Susu Ibu (ASI) pada Ibu Postpartum di Rumah Bersalin Wangi Lestari Kelurahan Utama Kecamatan Cimahi Selatan Tahun 2014. Jurnal Kesehatan Rajawali, Vol. 4 No. 7, Oktober 2014: 36-43

10.Mawaddah, S. 2016. Efektifitas Pijat Oksitosin dan Perawatan Payudara Terhadap Kelancaran Produksi ASI pada Ibu Post Sectio Caesarea di RSAD Wira Bhakti Mataram tahun 2015. Media Bina Ilmiah, Vol. 10 No. 3, Maret 2016: 48-52

11.Hamdana. 2010. Perbandingan Produksi ASI pada Ibu Menyusui Antara Persalinan Spontan dengan Persalinan Seksio Sesaria di RSIA Pertiwi Makassar. Tidak dipublikasikan. Makassar: Jurusan Keperawatan Universitas Negeri Alauddin Makassar
12.Irianto, K. 2014. Gizi Seimbang dalam Kesehatan Reproduksi (Balanced Nutrion in Reproductive Health). Alfabeta: Bandung

13.IDAI. 2013. Air susu ibu: Stres dan Cinta. Arsip Ikatan Dokter Indonesia (IDAI). (Online), cited 29 Mei 2018

14.Hesti, K. Y., Pramono, N., Wahyuni, S., Widyawati, M. N., and Santoso, B. 2017. Effect of Combination of Breast Care and Oxytocin Massage on Breast Milk Secretion in Postpartum Mothers. Belitung Nursing Journal, Vol.3 No.6, November December 2017: 784-790

15.Rahayuningsih, T., Mudigdo, A., dan Murti, B. 2016. Effect of Breast Care and Oxytocin Massage on Breast Milk Production: a study in Sukoharjo Provincial Hospital. Journal of Maternal and Child Health, Vol. 1 No. 2, 2016: 101-109

16.Retnowati, Y., dan Ramadhani, C.S. 2016. Perbedaan Lama Pengeluaran ASI pada Ibu Postpartum yang Dilakukan Perawatan Payudara dengan Pijat Oksitosin. 2-Trik : Tunas-Tunas Riset Kesehatan, Vol. 6 No. 4, November 2016: 181-186

17.Nilamsari, M.A., Wagiyo dan Elisa. 2014. Pengaruh Perawatan Payudara terhadap Kelancaran Ekskresi ASI pada Ibu Pospartum di Rumah Bersalin Mardi Rahayu Semarang. Jurnal Ilmu Keperawatan dan Kebidanan (JIKK), 2014: $1-7$

18.Wulan, S., dan Gurusinga, R. 2017. Pengaruh Perawatan Payudara (Breast Care) Terhadap Volume ASI pada Ibu Postpartum (Nifas) di RSUD Deli Serdang SUMUT Tahun 2012. Junal Kebidanan Harapan Ibu Pekalongan, (Online), Vol. 1 No. 5 (https://www.researchgate.net) diakses 24 Mei 2018

19.Wijayanti, T., dan Setiyaningsih, A. 2017. Perbedaan Metode Pijat Oksitosin dan Breast Care dalam Meningkatkan Produksi ASI pada Ibu Postpartum. Jurnal Komunikasi Kesehatan, Vol. 3 No. 2, 2017: $1-12$ 